\title{
Corporate Tax Planning Practice: A Bourdiesian's Perspective
}

\author{
Holy Kwabla Kportorgbi (Corresponding author) \\ Accounting and Finance Department \\ Ghana Institute of Management and Public Administration, Ghana \\ E-mail: hkportorgbi@gimpa.edu.gh \\ Samuel Gameli Gadzo \\ Department of Banking and Finance \\ University of Education, Winneba, Ghana \\ John Gartchie Gatsi \\ Department of Finance \\ University of Cape Coast, School of Business, Ghana
}

Received: October 17, 2018 Accepted: November 7, 2018 Published: November 7, 2018

doi:10.5296/ijafr.v8i4.13791

URL: https://doi.org/10.5296/ijafr.v8i4.13791

\begin{abstract}
This paper departs from traditional taxonomy of tax planning research that treats structures and actors as independent of each other. Using multiple semi structured interview of two major stakeholder groups-tax practitioners and tax researchers, the paper attempted social construction of tax planning practice. Emerging themes from the data reflects three postulates in Bourdieu's social practice theory.

Our findings establish tax planning as a social practice, under the meaning of Bourdieu's theory of social practice. Structuring properties, in the form of habitus of actors and their valuable tax planning capital, interract, in a dialectic manner with tax structures to produce tax practice.
\end{abstract}


Our findings dispel traditional conception of tax planning structures and actors as independent of each other. The findings, thus support a notion of structure-actor duality. We postulate a framework comprising field, capital and habitus interacting to explain variations in tax planning practice across space and time.

On the strengh of our finding that tax planning practice invoke serveral issues in other disciplines, we recommend that researchers in the field of accounting draw from theories in behavioural sciences.

Keywords: Tax planning, Bourdieu, Tax field, Capital, Habitus, Structure-actor-duality

\section{Introduction}

Research in tax planning is as old as its underlying theories (see for instance, Hoffman, 1961) yet skewed towards a horizon that magnifies tax structures against tax planning actors (Hanlon and Heitzman, 2010). With an arguably erroneous conceptualization of tax planning from structure-actor dualism perspective (as opposed to structure-actor duality) a vast amount of research effort took for granted foundational behavioural issues and focused on matters of magnitude, determinants and consequence of aggressive tax planning. For instance Hanlon and Heitzman's (2010) reviewed over three decades empirical studies in the field of tax planning and observed that research in the area is at a mature stage, yet no consensus on the very concept of tax planning (avoidance).

There were also contradictory findings on relationship between tax planning and firms' financial and market performance (see for instance Adbul-Wahab and Holland 2014, Kawor and Kportorgbi 2014). In recent time, researchers sought solace in corporate governance theories to explain inter-firm and intra-firm variations in tax planning activities (Armstrong, Blouin, Jagolinzer and Larcker 2015; Taylor, Richardson, and Lanis, 2015, Adbul Wahab and Holland 2014, Kawor and Kportorgbi 2014; Wang 2011, and Dyreng, Hanlon, and Maydew 2010).

Our argument is that clarity of findings in the area of tax planning research could improve when researchers perceive tax planning as a social practice; with a dialectic interaction between tax planning structures and human agencies (structure-actor duality). With this perspective, relational issues in the field of tax planning could be explained from three perspectives; (1) variations in tax planning structures across time and space (traditional); (2) variations in agencies' (tax planning actors, regulatory agencies, tax advocates) behaviour across time and space and (3) combine effect of variations in (1) and (2). To explore this seemingly expanded frontier of tax planning theory, there is the need to revert to fundamental issues of tax planning practice reconstruction- a core issue addressed in this paper.

This paper responds to two of the fundamental questions; (1) what does tax planning mean to key stakeholders? (2) How is tax practice produced across time and space? In order to address the first question, we departed from traditional objective ontological and epistemological stance. Our ontological stance in this paper is that tax planning is a social practice and best constructed from actors perspective. Similarly, this paper resisted the 
attempt of explaining production of tax planning from a structure-actor dualism perspective (as observed in Adbul-Wahab and Holland 2014, Kawor and Kportorgbi 2014(Note 1)).

Our approach to socially (re)construction is not new in accounting tax research. Currie, Tuck, and Morrell (2015) socially engaged senior tax inspectors in the UK to understand role transition for professionals. Again, Gracia, Louise, and Lynne Oats (2012) advocated for boundary work in the area of taxation and tax practice. Similarly, Picciotto (2007) argued for tax regulation to be viewed as a reflexive process mediated by sociolinguistic practices.

The need for social reconstruction (as we seek to do) require a relook at theoretical perspectives. We departed from known theoretical perspectives (for instance, Hoffman's (1961) tax planning theory and Scholes, Wolfson, Erickson, Maydew, and Shevlin's (2008) tax planning framework). We yielded to Maydew's (2001) admonition for tax researchers in accounting to explore theoretical alternative from other fields. In the quest for a suitable, theoretical grounding, work of Malsch and Gendron (2011), Gracia, Louise, and Lynne Oats (2012), Van Aaken, Splitter, \& Seidl (2013), Killian and O'Regan, P. (2016) shaped our choice for Bourdieu's $(1977,1990)$ social practice theory. We used Bourdieu's $(1977,1990)$ social practice theory as a sensitizing device (as opposed a theoretical lens). Recent tax legislation in Ghana (Tax Amnesty Act, 2017, Act 955) was adopted as a point of reference in examining our research questions. The tax amnesty act was deemed appropriate for our study because it was one of few tax laws that (on the face of it) promises tax remission rather than levying tax.

The remaining sections of this paper are structured as follows. First a review of theoretical underpins of our work in two sub-sections, the concept of tax planning and Bourdieu's social practice theory, within the context of accounting research. Secondly, we present empirical perspectives, with a bias towards behavioural tax research findings. Thirdly, we detailed the research methods applied in the study. The penultimate section provides results and discussion of the findings. The final section provides summary, conclusions and suggestions for further studies.

\section{Theoretical Underpins of Tax Planning Research}

We explore theoretical underpins of tax planning research from two perspectives; (1) the concept of tax planning (as known in tax research); (2) Bourdieu's social practice theory as a potent theory for grounding behavioral issues of tax planning research. These areas are discussed next.

\subsection{Conceptualising Tax Planning}

We begin by issuing a "caveat to our audience that "meanings" ascribed to the concept "tax planning" in this session, at best, serve as a sensitising device and did not influence our exercise of social (re)construction at the empirical stages.

Dyreng et al. (2008) and Hanlon and Heitzman (2010) broadly described tax planning (avoidance) as a continuum of activities aimed at reducing tax burden. From this perspective, tax avoidance captures two extremes, tax favoured transactions at one end and aggressive tax 
behaviours (tax evasion) at the other end. Between the two extremes are various schemes (tax plans) to specifically reduce taxes. Slemrod, Joel, and Shlomo Yitzhaki (2002) defined tax planning in a manner that makes it synonymous to tax avoidance but distinct it from a related illegal practice-tax evasion. Broadly, conceptual meanings (Hanlon and Heitzman, 2010; Dyreng et al., 2008; Slemrod, Joel, and Shlomo Yitzhaki, 2002) conform to Hoffman's (1961) age old propositions on tax planning. According to Hoffman (1961), tax planning is gamut of pre-meditated acts by a taxpayer or his assigned agent, to arrange his financial transactions in a manner that ensure minimum tax liability on transactions.

The conceptual meanings for tax planning are conscious of legal web of tax planning (structures) but took for granted how agents who give meaning to the structures influence affect the structures.

Kumbour, Ali-Nakyea and Demetia (2017) described tax planning by reference to practice. According to the authors, tax planning involves anticipating circumstances and the identification of opportunities; within a prevailing tax law regime to minimise or defer tax liabilities. From this perspective, tax planning connotes four interrelated sequences: (1) understanding tax law; (2) identification of tax-minimizing opportunities; (3) scheming to exploit the opportunities, and (4) implementing the scheme. According to Bonner, Sarah, Davis, and Jackson (1992), these sequences of acts require cognitive skills and personal disposition of the tax planner. Cognitive skills and personal dispositions, as explained by Bonner et. al. (1992) falls outside traditional accounting discipline. Considering the major role of these behavioural dimensions, it is critical to seek solace in behavioural sciences to fully explore dynamics of tax planning.

Our argument is that tax researchers in accounting ought to view tax planning as a social practice. From social practice perspective, tax planning is viewed as dialectic between social structure (in this case, tax environment) and human agency (the various actors at macro, meso and micro levels) working back and forth in a dynamic relationship. Tax researchers ought to continually examine interactions between tax planning actors and the tax field to explain variations in the social practice across time and entity.

In summary, we have traced that in literature, the concept of tax planning is predominantly objectified thus research focus in the area largely drive toward ascertaining quantum and determinants. We have also pointed out that tax planning practices have a strong scent of behavioural science and that research in the area could be improved if tax planning is perceived as a social practice dialectic interaction between actors and structures.

\subsection{Bourdieu's Social Practice Theory in Accounting Research}

Malsch and Gendron (2011) traced how writings of a French philosopher, Pierre Bourdieu on social structure (field), power relations, and a theory of individual (habitus) have been imported into accounting research. We draw on thse three concepts in this paper, thus it is pertinent to briefly explore them.

First is the notion of theory of social structure referred to as "field". Bourdieu (1993) described the field as a configuration of relationships between the social positions the 
occupants happen to hold within the given configuration of social space. Social fields are liken to "battle ground" where the actors enact practices to reinforce or jostle for power.

The second concept in Bourdieu's triad is the notion of capital. Transactionary powers of various actors depend on their quantum and quality of capital they yield in the field, their tagetories within the field and their ability to adjust to rules inherent in the field. Bourdieu (1993) identified three forms of capital; economic, cultural and social capital. The form of field-specific capital (resource) that gives an actor an advantage to command influence in the field is termed operative capital. Actors within the social field are inclined to trading any of their capital for the operative capital. Social inequalities and power differential in the social field could be attributed to the quality and quantum of capital yieded by the the social actors.

Aside dynamics of jostling for influence in the social field, Bourdieu (1993) underscores that social actors' individual dispositions affect their behaviours. Individual-specific dispositions are in-built transposable understandings and ways of thinking referred to by Bourdieu "habitus". Habitus is formed and produced through long processes of inculcation during a lifetime, including socialization and formal education that predispose agents to act and react in certain ways in particular situations according to the amount of capital they possess. Habitus is therefore both a structuring structure, in that it organizes practices and the perception of practices, and a structured structure, in that the principle that organizes the perception of the social world is itself the product of an internalization of the social world (Bourdieu, 1984, cited in Malsch and Gendron, 2011). Bourdieu's concept of habitus dispels the notion that decision makers follow, strictly, a well-thought out valuation of capital transformation. While this objective valuations are possible, the process is also influenced by an already in-built inclination and disposition of the decision maker (Golsorkhi et al., 2009).

Our focus here is to relate these Bourdeusian concepts; field, capital and habitus into the study of taxation largely, and narrowly to tax planning. In prior section we have illustrated how the concept of tax planning should be seen as a social practice that involves interraction of structures (tax environment) and human actors in a dialectic manner.

\section{Some Empirical Perspectives}

Bourdieusian theory has been visible in accounting research in the recent decade. We make reference to contributions of Tremblay, Gendron \& Malsch (2016); Larsen (2015), Wynter (2014) and Van Aaken, Splitter, \& Seidl (2013).

Tremblay, Gendron \& Malsch's (2016) work is not directly related to taxation, it captures our attention for at least two reasons; (1) it draws on Bourdieu' (2001) concept of symbolic violence to explore perceptions of legitimacy surrounding the presence of female directors; (2) its finding provide a frame for discussing the role habitus of actors' play beyond traditional arguments of gender. Among other findings, Tremblay, Gendron \& Malsch's (2016) reported that existence of females on Boards was justified and normalized, based on competences and contribution as opposed to traditional thinking that they should be justified to create gender balanced boards. In our framing of tax planning practice (see figure 1), we asserted that gender and other demographic variables could provide micro level explanation for tax 
decision makers' influence in tax planning. Tremblay, Gendron \& Malsch (2016) thus provide a general frame for explaining micro-level habitus, (in our case) for explaining inter and intra firm variation in tax planning practice/behaviour.

Larsen (2015) also provides an illustration of how Bourdieusian triad; field, capital and habitus. Larsen (2015) did not make explicit reference to Bourdieu or his "triad" but extensively relied on Gracia \& Oats (2012) who grounded their study on Bourdieu's writing. Of interest to us is how Larsen's (2015) work underscores interaction between tax structures of Sweden and human agencies (Swedish tax authorities and tax paying entities). Lassen posited that the distinction between taxable income taxable and tax-free income is determined by "common sense". Lassen's finding dispel the notion that structures (Swedish tax laws) are superior to agencies (tax authorities and tax paying entities). His findings discount the notion that human actors merely fulfil structures (structure dualism).

Our third empirical reference is Wynter (2014). Using Portmore Municipality in Jamaica as a case, the author provided evidence of struggles in the property tax field among the tax authority, the politicians, the developers, the local authorities, the central government and the taxpayers and how each one the actors apply their capital to maintain or dominate its position within the property tax field. Wynter (2014) adapted Bourdieu's social practice theory to explain maneuvres, tax planning schemes from tax paying entities and counter reactions of tax authorities. The study was however silent on the role of individual disposition (habitus) of the actors.

Van Aaken, Splitter, \& Seidl (2013) draw on Bourdieu's social practice theory to explain pro-social behaviour of firms. The authors' suggested that mangers at the firm level explore their CSR budget power to yield social power. The authors argued that the extent of CSR deployment effort depends on the social field and individual disposition (habitus) of the managers. Our argument is that if CSR and taxation are two side of same coin. While the former represents voluntary contribution towards social welfare, the latter represents mandatory contribution; thus both should be construed as social practice under the meanings intended by Bourdieu.

In summary, we have highlighted three pertinent issues in this section. Firstly, Bourdieu's social practice theory is not alien in the discipline of accounting and in tax research to be specific. Secondly, there has been ample evidence in literature that Bourdieu's triad "habitus, capital and field" are adaptable to tax planning. Finally, that the theory provides an alternative to explore weightier matters in varied areas of accounting literature where traditional theories in accounting fall short.

\section{Methodology}

The purpose of this study is to socially construct the concept of tax planning and subsequently explore how tax practice is produced across time and space. As interpretivist researchers, we assumed that tax planning is a social phenomenon and ought to be socially constructed. We were careful not to impose an "objective" meaning on the study participants. Theoretical underpins in literature review sessions provide a sensitising devise for teasing out 
and interpreting socially constructed meanings.

Primary data was collected through semi-structured interviews of tax practitioners and auto-textual analysis of tax academics and tax practitioners. The tax practitioners' group comprises seven tax experts conveniently selected from two of "big-four" audit firms (Note 2) and a foremost tax and legal practice firm in Ghana. To be selected as a respondent, one must meet two pre-requisites; (1) must have a considerable experience as a corporate tax consultant with a working knowledge on the selected reference tax law in Ghana (Tax Amnesty Act, 2017, Act 955); (2) should either have acted as a consultant for policy maker in Ghana (government) or as a consultant for tax policy implementing authority (Ghana Revenue Authority). These two pre-requisites are needful to ensure data is collected from a source that embodies at least perspectives of ta- paying and tax-receiving entities.

The seven tax practitioners comprise two topmost officials each from two international audit/tax firms. The seventh person is the head of tax unit of a leading local tax/law firm in Ghana.

The second group comprises eighteen (18) tax researchers/lecturers from three public universities in Ghana. To be selected for this category, one must have been highly skewed towards tax research.

Both groups of respondents were purposively sampled, so as to ensure data emanates from knowledgeable and willing respondents. We did not impose on ourselves a fixed sample size. We were open to collect insight from as many respondents that meet our selection criteria until we reach a point of data saturation as described by Guest, Bunce \& Johnson (2006). For the tax practitioners' group, there were five independent interview sessions with seven respondents. Interviews and auto textual were independently held for all the eighteen selected tax academics.

Data from the tax practitioners'group was collected using interview guide. Broad areas of the interview guide draws from the research questions. First we elicit the respondents' own construction of tax planning. The secondly we sought insight on the respondents' experience and practice of tax planning. Thirdly we set out to explore any emergent theme that may arise from the interview.

Data from tax academics was collected using two techniques. First an auto-textual technique where we requested the respondents to write their own meaning of the concept of tax planning and how they conceptualise tax planning variable. Following is a semi structured interview session to explore further dimensions in their textual responses.

Prior to the interview, the selected interviewees were contacted and appointments booked. The purpose of the study was duly sent to the respondents together with statements regarding duration of the interview, consent and withdrawal of consent, confidentiality and anonymity. In all interview sessions span over three weeks. Each interview session lasted an average of thirty minutes for the practitioners group and twenty minutes for the tax academics group.

For purposes of maintaining anonymity of the respondents, we refer represent the respondent 
groups as $\mathrm{A}$ and $\mathrm{B}$ respectively for academic and tax practitioners group. References are made to respondents based on which group they belong and the sequence of interview. For instance, $\mathrm{B}_{4}$ represents the $4^{\text {th }}$ tax practitioner we interviewed.

Bourdieu's social theory emerged as an appropriate lens for the discussion of the results.

\section{Results and Discussion of Findings}

We structure the results of the study in three sections. First, the concept of tax planning as socially constructed by the respondents. Secondly we explored evidence of Boardieu's triad; tax planning field, capital and habitus. Thirdly we present results on how interfirm and intra firm variation in tax planning practice are explained by interractions among "tax planning field", capital and habitus of various players.

\subsection{Social Construction of Tax Planning}

Respondents in each of the two apriori groups were requested to construct their own meaning of tax planning. We discuss findings from the tax academic group, followed by responses from the tax practitioners' group.

Five constructs emerged from the autotext responses of the academic group. Three of the constructs, opportunity identification, mindfulness of tax laws, and execution of of tax plans were pervasive in all the eighteen responses in the tax academic groups.Aside these three constructs, a proportion of the sample (22.2\% and $38.9 \%$ respectively) aluded to tax law knowledge and tax plan evaluation.

One keen induction from from this result is that the concept of tax planning invoke more behavioural issues than core issues in accounting discipline. For instance, there is a strong influence of human actors in all the emergent five constructs. Tax planning opportunity identification for instance involves both expertise (core accounting) and experience and willingness (behavioural issues).

In the auto text responses, there was a common view that tax planning activities are subject ot given tax law regimes. The auto texts responses suggest that tax planing entities do not have any influence on tax structures; and that tax planning connotes observing the limitations imposed by the structures. The results, in this respect, was unanimous. Results from various interviews in this group largely resonates with the textual results, yet shows a partial sign of auto-textual discordance. While two-third of the respondents rejected that tax planning cover issues of engagement and negotiation with tax structures (or their representatives), a third took a position that suggest that tax planning covers engagement, lobbying, negotiation and pre-emption of tax laws. According to this minority group, tax lobbying or advocacy, and general frame of activating private rulling regimes fall within the scope of tax planning.

Although a lager proportion of tax academic group construct tax planning to conform with traditional views in literature (see for instance, Hanlon and Heitzman, 2010; Dyreng et al., 2008; and Hoffman, 1961), there is an observably significant minority who holds a view suggestive of an expanded boundary span. To this group, tax planning is happens within a negotiated field, as opposed to a given field. From this expanded frontier, the minority group 
holds that tax planning benefits accrue from two sources; (1) wielding a superior stake in the tax field (through superior engagement, lobbying, and positioning) with tax structures; and (2) efficient identification, scheming and execution of tax plans. This concept of tax planning fit within the general framework of Bourdieu's theory of social practice.

Majority of respondents in tax academic group subscribe to the notion that tax structures and agents are independent while an emerging minority holds a view similar to structuration theories.

Now let us review results from the second group; the tax practitioners. First notable trend was that majority of them begin their responses with an assertion that tax planning is a complex activitity. Majority of them prefered to describe various aspects of thier "complex act", rather than providing a definitive frame (as done by respondents in tax academic group).

First respondent $B_{1}$, who was responding to our question that what in his opinion count as tax planning has this to say:

"...being on the right path of the tax law, then craftily scheming to take advantage of all benefits (both intended and unintended) to reduce the clients' burden". It is involves continual learning, staying ahead of the game, participating in the policy and keeping your scheme tight, legally and morally. The other aspect of tax planning... to communicate the scheme to your clients and managing their expectations".

$\mathrm{B}_{1}$ 's response seems to encapsulate all aspects of tax planning, as constructed by the tax academics group. Additionally, it capture four issues; (1) tax planning involves continual learning; (2) tax planning as a game; (3) moral implicationof tax planning and (4) stakeholder expectation management. Tax planning conceptualised as a learning process means it involves cognitive skills and processing of the respondent (a behavioral issue). Tax planning as a game connotes anction and reaction of various players. This is typical of Bourdieu's description of a social field. Moral implication of tax planning invokes Bourdieu's postulation of Habitus. The notion of stakeholder expectation management involves the use of ones' "capital". All these emergent themes have their roots in behavioural sciences; re-enforcing our argument that indepth understanding of tax planning lies in a field other than accounting.

Respondent $\mathrm{B}_{2}$ has this to say:

“...I can't define tax planning because it is complex, but $i$ will provide two perspectives..first perspective, acting within existing laws to minimise your client's tax exposure; second perspective, tax planning involves forecasting tax laws and advising clients to position their acts favourably for upcoming tax legislation. This is what I call contemporary tax planning, that is where the world is moving to ..."

$\mathrm{B}_{2}$ 's response resonates also with views from minority in tax academic group who suggested that tax planning connotes both reactive and proactive dimensions. According to $\mathrm{B}_{2}$, reactive tax planning is traditional and gradually giving space to a more proactive tax planning practice. 


\section{$\triangle$ Macrothink}

International Journal of Accounting and Financial Reporting

ISSN 2162-3082

Respondent $\mathrm{B}_{5}$ and $\mathrm{B}_{7}$ in independent interview sessions confirmed and provided further insight on $\mathrm{B}_{2}$ 's proposition of proactive tax planning. The respondents provided as follows:

Respondent $\mathrm{B}_{5}$

"tax planning complex and dynamic because, in the past our business was to help clients reduce non-compliance cost, so we use our knowledge and expertise to advise them to eliminate tax non compliace cost.. recently, everyone know the law, your value as a tax planner stems from positioning to your client to forecast the tax environment, its now an attack game as opposed to beign reactive"

\section{Respondent $B_{7}$}

"my dear the game has changed, no client gives you cash for advising them on compliance.. even before they engage you, they evaluate your influence at tax policy level and your valuable contacts; no job for you if you cannot pre-empt tax direction and advise on non-obvious course of actions".

In their respective submissions, all the tax practitioners respondents agree that the concept of tax planning goes beyond drawing on loopholes from existing laws to achieve tax advantage. Tax planning, according to the tax practitioners group, is a proactive game, which involves anticipation and participating in tax environment, drawing on ones' capital (expertise, financial, contacts) to ensure maximum tax advantage.

In summary, our social construction efforts yielded at least two interrelated new findings. Firstly, there is a unanimous perspective from tax practitioners group that tax planning environment is not given but negotiated. This view is shared by minority groups in tax academics group. Relatedly, the results suggest an an established awareness that tax planning, in contemporary times, draw on tax planners' capacity and willingness to engage and participate that tax planning environment; aside traditional scheming to eploit loopholes in tax laws. Based on constructions of the two groups, we posit figure 1 as a concept map of tax planning.

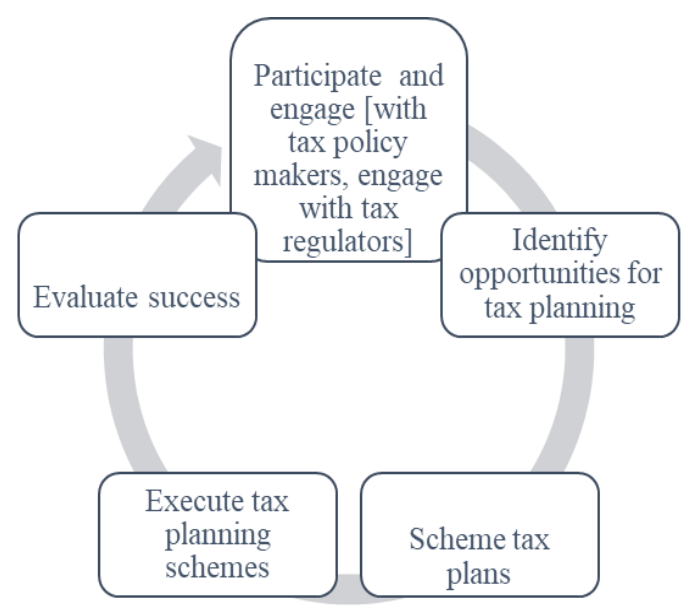

Figure 1. Tax planning concept map 


\subsection{Tax Planning as a Social Practice}

Here, we adduce evidence that grounds our conviction that tax planning is a social practice, within the meanings of Bourdieu's social practice theory. First, we found traces of Bourdieu's triad; capital, field and habitus. Next we establish the dialectic interation between tax planning structures and human actors within the frames provided by Bourdieu. We then establish how the interraction between tax planning structures and human actors provide a frame for explaining variation in tax planning practice accross time and space.

\subsubsection{Traces of Bourdieu's Triad: Field, Capital and Habitus}

It is pertinent to point out that all the seven respondents in the tax practitioners' group are foremost tax resource persons both at policy front in Ghana and for large multinationals. Detailing their stature at the tax front in Ghana would, however, mean breaching the anonymity clause we agreed on before the interviews. We engaged the respondents to understand why a multinational would select them as tax planning consultant, what they do as tax planning consultant for firms and why they accept to act as tax consultant for government and governmental agencies. The themes that emerged from the responses reflect Bourdieu's postulation of field, capital and habitus.

Specifically, we analyse responses to the question why a large multinational firm would choose them as their tax planning consultants. In the following table 1 , we provide extract of their responses.

Table 1. Influences on tax planning consultant selection decision

\section{Respondent Response}

$\mathrm{B}_{1} \quad$ "Tax planning is a complex process, they look out for the firm who has the capacity, contacts, the know-how'... [specific name] has both the name and the capacity to handle any sophisticated transaction in the area of tax"

$\mathrm{B}_{2} \quad$ "We are noted for our high ethical standard, you know [name of firm] is international in character. These multinationals do not want any trouble with tax authorities, and they trust our professional judgment".

$\mathrm{B}_{3} \quad$ "They know we are in tune with developments in the field. They would rather trust their tax issues with us and concentrate on their business... tax planning consultancy is a game of trust, expertise and insight...we stand tall with these qualities"

$\mathrm{B}_{4} \quad$ "We control do tax planning consultancy for almost all the four major players in [specific] industry. For firms in these industries, they are already settled on who to trust their tax issues with...sometimes we are surprised that [government agency] recommend tax clients to us... we do it right, we explain 
the risks and uncertainties on each suggested tax planning scheme".

$\mathrm{B}_{5}$

"All of us in the tax consulting industry have varied philosophies towards tax planning; some are conservative, others are aggressive, while others take middle stake... large multinationals know this. They contract you base on their specific need and your philosophy".

$\mathrm{B}_{6}$

"For multinationals, they already know what you offer...your standing with those who matter at GRA and policy level... they[companies] select based on who can best get the job done".

$\mathrm{B}_{7}$

"When firms select tax planning consultants, they look out for names, experience... who best represents them at policy and GRA [Ghana revenue Authority] forum... we have the men, the links, the experience".

Source: Fieldwork (2018)

In their various submissions, the respondents posited that tax planning is a specialized area (field). The respondents mention various players in the field as Ghana Revenue Authority government agencies, and tax planning agencies. To be successful in the field, the respondents mentioned resources that position a tax consultant to wield power. For instance, the respondents mentioned ethical standing, experience, contact, expertise as various forms of resources that distinct tax consultancy firms. These are what Bourdieu referred to as "capital". Although individual (micro level) habitus was not expressly evident in the quotes, they were apparent in their subsequent submissions.

We proceed to solicit from respondents why they accept to act for government and government agencies. Their responses provide a clearer insight on the jostling and lobbying in the tax planning field. It also provides grounds for our earlier finding that tax planning field is not "given" but negotiated. For instance, respondent $B_{5}$ has this to say:

"... it is (tax planning) about participating, shaping, and anticipating the next move of tax policy makers; testing the interpretation of GRA on grey areas; and devising client-specific schemes to achieve your tax objectives... personally, I regularly study political terrains and devise tax plans for clients...".

Respondent $\mathrm{B}_{5}$ reflects maneuverings and capital transformation moves that occur in a social field. Similarly, $\mathrm{B}_{1}$ and $\mathrm{B}_{6}$, admitted that enthusiasm of tax practitioners at forum of tax policy makers is part of a larger frame of tax planning: to "dig into the mind" and test "pulse" of tax policy makers. $\mathrm{B}_{1}$ provided as follows:

"we participate actively in tax legislation discussions, there we have foreknoledge on the next tax move, strive to sway tax legislation and position our clients favourably in a concluded tax regimes".

Respondent $\mathrm{B}_{6}$ placed proverbially, 
"we have an interest, we are a coach to our clients, to sit down and work within a concluded tax law is to become a commentator instead of being a coach".

Finally, respondents provided traces of how habitus of stakeholders, particularly, tax planning entities influence tax planning actions of firms. In table 2, we provide summary of these traces.

Table 2. Evidence of tax planning "habitus"

\begin{tabular}{|c|c|c|}
\hline $\begin{array}{l}\text { Form } \\
\text { of } \\
\text { Habitus }\end{array}$ & $\begin{array}{l}\text { Habitus-forming } \\
\text { variables }\end{array}$ & Evidence source \\
\hline $\begin{array}{l}\text { Individ } \\
\text { ual }\end{array}$ & $\begin{array}{l}\text { Expertise of tax } \\
\text { decision } \\
\text { maker,experience } \\
\text { of tax decision } \\
\text { makers, } \\
\text { risk-aversion, age } \\
\text { of key tax decision } \\
\text { makers, }\end{array}$ & $\begin{array}{l}\text { All A group respondents, and } 4 \text { respondents in B group } \\
\left(\mathrm{B}_{1}, \mathrm{~B}_{4}, \mathrm{~B}_{6}, \mathrm{~B}_{7}\right) \\
\text { For instance; } \mathrm{B}_{6} \\
\text { "tax planning posture of firms depend on several issues: } \\
\text { knowledge of the key finance person on tax, risk appetite } \\
\text { of the decision makers, cost of consulting on tax planning, } \\
\text { reputation issues, and so on ... so when you have a } \\
\text { manager whose performance is tied to after tax profit..they } \\
\text { would not leave tax planning option unexplored". }\end{array}$ \\
\hline
\end{tabular}

$\begin{array}{llr}\text { Situatio } & \text { Boardroom } \\ \text { nal/fir } & \text { support, tax } \\ \text { m level } & \text { culture, tax } \\ & \text { knowledge level of } \\ & \text { the board, type of } \\ & \text { investors (foreign } \\ & \text { or local). }\end{array}$

All respondents inrespondent B group

Notable quote: B4

“...variety of factors, knowledge and experience from their past tax planning, the risk appetite of the board and culture of the firm of the firm as I said.. even where the investors come from and nature of their company structure... influence their willingness to emback on tax planning...”.

Habitus forming variables have been refered to severally as corporate governance mechanisms. For instance, Kawor \& Kportorgbi (2014); Abdul-Wahab \& Holland (2012); Wang, (2011); and Dyreng, Hanlon and Maydew (2010) used combination of these variables as proxies for corporate governance. Their findings on the role of corporate governance, contradict and does so for good reasons. Our findings here provide that these variables are structuring (human and behavioural) and interdependent properties as opposed to independent and mutually exclusive varriables (so assumed by the previous referenced authors). 


\section{Macrothink \\ International Journal of Accounting and Financial Reporting \\ ISSN 2162-3082 \\ 2018, Vol. 8, No. 4}

\subsection{Dialectic Interaction between Tax Planning Structures}

In this final section, we induce from the results that habitus and capital serve as tax planning structuring properties. We postulate that tax planning structures both affect and are affected by structuring properties (habitus and capital).

We asked the respondents to proffer their opinion on why there are variations in tax planning activities of across firms and time. The respondents mentioned among other things, variation in tax laws, changes in management, tax planning expertise, tax culture, and inclination of firms' governing boards. For instance, $B_{3}$ responded as follows [emphasis ours']:

“...variations in tax laws [tax planning field], tax culture, budget power [tax planning capital] ... [see] when management changes hands, tax planning expertise and appetite change [habitus], when there are changes in governing boards, tax culture change [interractions between capital and habitus]... you know we may even have changes in tax laws and tax consultants [interraction between structures, capital and habitus] ... all these account for variations in tax planning postures".

Respondent $\mathrm{A}_{2}$ also provided a response that resonates with the rest of respondents in the tax academics group. According to $\mathrm{A}_{2}$ :

“... tax planning behaviour is shaped by the firm's ability to engage well with the tax law [structure] and this ability depends on the level of boardroom support [capital] and the tax planning entities knowledge and skills [habitus]... a change in any of these factors can explain the variations you talked about".

In analysing responses accross the two groups, there emerged a trend that tax planning practice of firms are influenced by (1) composition and quantum of "capital" weilded by tax participants at the "tax planning field" (2) propensity of participants to transform these capital into valuable tax planning capital (3) tax planning specific "habitus" of the tax planning entities or their agents. We also postulate (based on our evidence) that level of rivalry in the tax planning field is influenced by capital and habitus structuring properties. Figure 2 provides summary of our findings. 


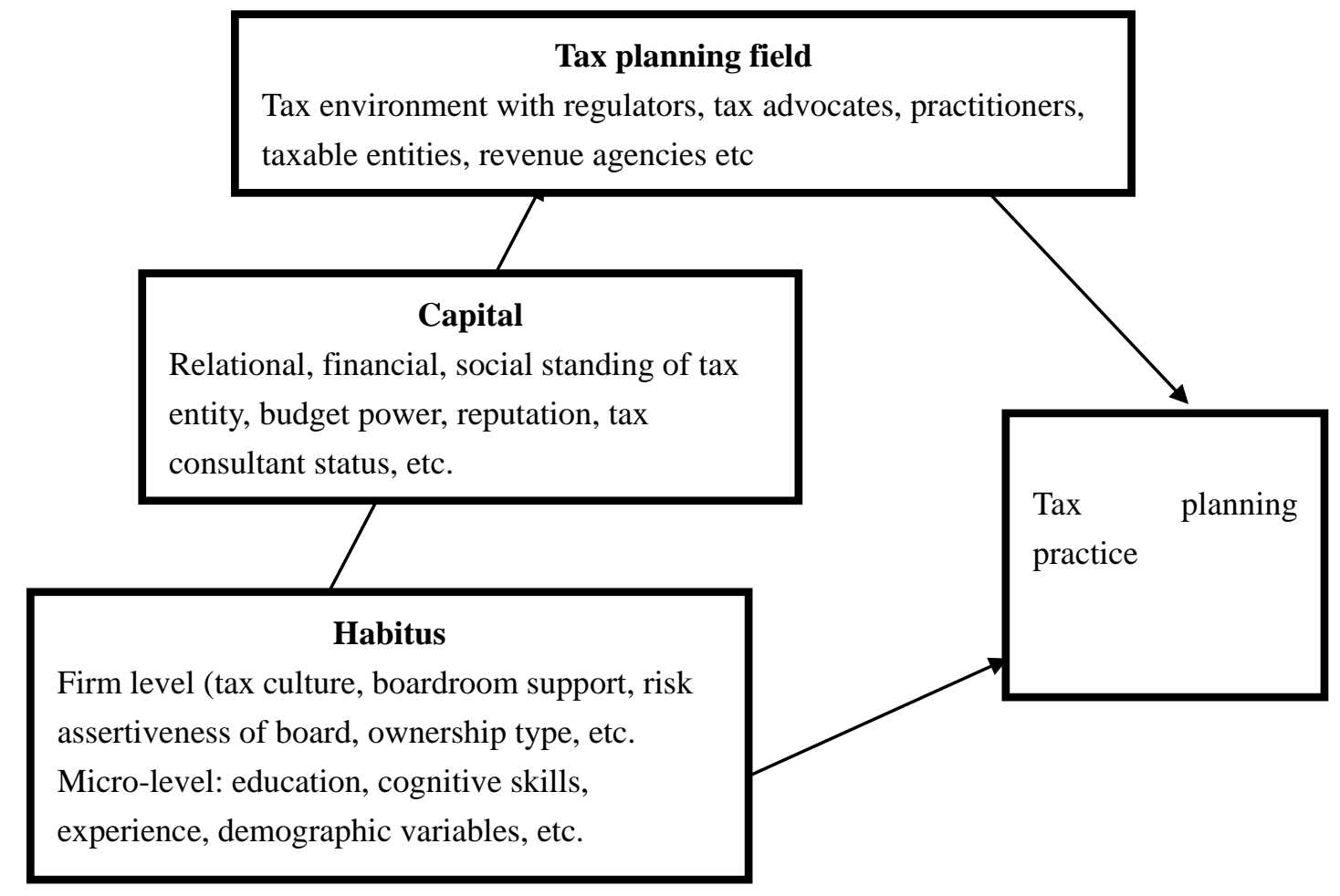

Figure 2. Dialectic interraction between tax planning structures and actors

Source: Fieldwork (2018)

Our findings could be summarised as follows: (1) that tax plannng of firms happen within a field; referred to as "tax planning field. The field represent tax structures within which various actors operate (Gracia and Oats 2012). In this field, tax policy makers perform their legitmate role of formulating tax policies and tax legislations. The regulators, with the tacit legitimation from government carry out their duties of implementing tax policies and ensure all players conform to the letter and spirit of tax laws. Within the field are tax consultants and "experts" who severally act as agents of tax incidents/impacts or consult for governmental agencies. Also in the tax field are tax paying entities and other stakeholders who are affected by existing or contemplated tax policy. Typical of a social field (described by Bourdieu), this field comprises persons with varied interests and continually witness jostling, maneuvres and lobbying for power. As a typical social field, there are power inequalities within the tax planning field.

Maneuvres and jostling for power and dominating moves of the participants in the tax field depends on quantum and quality of capital yielded by the actors in the tax planning field. Figure 2 also provides a number of capital types that facilitate or inhibit transaction of players in the field. Firms' tax planning behaviours are aided or inhibited by quality of relationships with other field participants, financial capital available for tax planning efforts, budget power of key tax decision makers, reputation of the tax planning firm and social and professional standing, status of tax consultant.

Finally, disposition (habitus) of the tax planning entities. Habitus comes in two levels, at the firm level and at the micro level. As shown in figure 1, tax culture, boardroom support, risk 
assertiveness, management style, motivation is but few factors that could influence firms' tax planning practice. Considering tax planning as a cognitive process, individual disposition of tax decision makers, such as education, skills, experience, education and other demographic variables count in explaining tax planning practice and behaviour of firms.

We assert that our conceptualisation of tax planning using the boaudieusian triad, provides a wider framework for both social (re)construction of the concept of tax planning and for explaining fluid issues that have not not been addressed adequately in current literature.

\section{Summary, Conclusion, Contribution and Limitation}

\subsection{Summary of Findings}

We engaged two groups of stakeholders in our quest to socially construct the concept of tax planning. The results support three notions. Firstly, we found that tax planning practice invoke serveral issues in behavioural sciences, and that researchers in the field of accounting need to draw from theories in behavioural sciences in order to explore deeper issues in the field. Secondly, there is a unanimous view among tax practitioners group that tax planning structures are not given but rather negotiated. In otherwords, tax planning actors could improve their tax planning lot by taking positions in the tax field rather than traditional postulation of only acting within "given" tax laws. This view is not however, popular with tax academic groups. Based on the results, we construct a tax planning practice to cover five (instead of 4 traditional) processes. These are (1) participation in tax planning field, (2) identification of tax planning opportunities, (3) scheming of tax plans (4) execution of tax plans, and (5) evaluation of tax planning outcome.

Our findings establish tax planning as a social practice, under the meaning of Bourdieu's theory of social practice. As a social practice, tax planning practice occurs in a field. Structuring properties in the form of habitus of acators and capital weilded by the actors interract in a dialectic manner to produce tax practice.

Our findings dispel traditional conception of tax planning structures and tax planing actors as independent of each other. The findings, thus support a notion of structurer-actor duality. We postulate a framework comprising field, capital and habitus interacting to explain variations in tax planning accross space and time.

\subsection{Our Contribution}

Although not a novel attempt, the paper is one of the pioneers in applying Bourdieu's theory in the area of tax planning. By this, the paper contributes to emerging trends towards synchronising behavioural sciences and taxation. Relatedly, the paper provided a broader frame for exploring reasons for variations in tax planning behaviour across time and space. Our study also provides some insight as to why recent approach in merging corporate governance and tax planning (avoidance) yield inconsistent results.

Our paper also produces a conceptual framework that depicts structure-agency duality as against pervasive conceptualisation from structure-agency dualism perspective. 


\subsection{Limitation of the Study}

This study provided a viewpoint of only two actors; tax academics and tax practitioners. There are other notable actors, such as tax authorities and taxable entities that have not been captured. We however, draw attention to the fact that our purpose is not to achieve statistical generalisation but rather to produce an analytical context-specific generalisation. Again inclusion of major tax practitioners, who mediate between taxable entities and tax authorities can effectively reduce unintended bias in our findings. Finally, the study did not provide statistical prove of interactions among the variables. This limitation is inherent in the qualitative approach we adopted for the study.

\subsection{Recommendation for Further Studies}

We recommend the following areas for further research. First a cross validation of our claim of difference in conceptualisation of tax planning across the two groups, through a methodology that guarantee statistical rigour and statistical generalization. Secondly we propose that further studies extend the discussion beyond the two groups we explored here. Finally we recommend that studies build on our non-statistical findings of interaction among the tax planning structures and the structuring properties. In specifics, a structural equation model could be adopted to validate our non-statistical claims.

\section{References}

Armstrong, C. S., Blouin, J. L., Jagolinzer, A. D., \& Larcker, D. F. (2015). Corporate governance, incentives, and tax avoidance. Journal of Accounting and Economics, 60(1), $1-17$.

Bonner, S. E., Davis, J. S., \& Jackson, B. R. (1992). Expertise in Corporate Tax Planning: The Issue Indentification Stage. Journal of Accounting Research, 1-28.

Bourdieu, P. (1990). The logic of practice. Stanford university press.

Bruno, V. G., \& Claessens, S. (2007). Corporate governance and regulation: can there be too much of a good thing?. The World Bank.

Currie, G., Tuck, P., \& Morrell, K. (2015). How hybrid managers act as "canny customers" to accelerate policy reform: A case study of regulator-regulatee relationships in the UK's tax agency. Accounting, Auditing \& Accountability Journal, 28(8), 1291-1309.

Desai, M. A., \& Dharmapala, D. (2006). Corporate tax avoidance and high-powered incentives. Journal of Financial Economics, 79(1), 145-179.

Dyreng, S. D., Hanlon, M., \& Maydew, E. L. (2010). The effects of executives on corporate tax avoidance. The Accounting Review, 85(4), 1163-1189.

Golsorkhi, D., Leca, B., Lounsbury, M., \& Ramirez, C. (2009). Analysing, accounting for and unmasking domination: On our role as scholars of practice, practitioners of social science and public intellectuals. Organization, 16(6), 779-797.

Gracia, L., \& Oats, L. (2012). Boundary work and tax regulation: A Bourdieusian view. 
Accounting, Organizations and Society, 37(5), 304-321.

Guest, G., Bunce, A., \& Johnson, L. (2006). How many interviews are enough? An experiment with data saturation and variability. Field methods, 18(1), 59-82.

Hanlon, M., \& Heitzman, S. (2010). A review of tax research. Journal of Accounting and Economics, 50(2-3), 127-178.

Haynes, K. (2012). Body beautiful? Gender, identity and the body in professional services firms. Gender, Work \& Organization, 19(5), 489-507.

Hoffman, W. H. (1961). The theory of tax planning. The Accounting Review, 36(2), 274-281.

Kawor, S., \& Kportorgbi, H. K. (2014). Effect of Tax Planning on Firms Market Performance: Evidence from Listed Firms in Ghana. International Journal of Economics and Finance, 6(3), 162.

Killian, S., \& O'Regan, P. (2016). Social accounting and the co-creation of corporate legitimacy. Accounting, Organizations and Society, 50, 1-12.

Kumbour, A.-N., \& Demetia (2017). Taxation in Ghana: Princples and Practice. Accra: Black mask publication.

Lanis, R., \& Richardson, G. (2011). The effect of board of director composition on corporate tax aggressiveness. Journal of Accounting and Public Policy, 30(1), 50-70.

Maydew, E. L. (2001). Empirical tax research in accounting: A discussion. Journal of Accounting and Economics, 31(1-3), 389-403.

Murphy, K. (2007). Procedural justice and the regulation of tax compliance behaviour: the moderating role of personal norms (No. paper0731). International Center for Public Policy, Andrew Young School of Policy Studies, Georgia State University.

Picciotto, S. (2007). Constructing compliance: Game playing, tax law, and the regulatory state. Law \& Policy, 29(1), 11-30.

Scholes, Wolfson, Erickson, Maydew, and Shevlin (2008). Taxes and Business Strategy: A Planning Approach (4th ed.). New Jersey: Pearson Prentice Hall.

Slemrod, J., \& Yitzhaki, S. (2002). Tax avoidance, evasion, and administration. In Handbook of public economics (Vol. 3, pp. 1423-1470). Elsevier.

Taylor, G., Richardson, G., \& Lanis, R. (2015). Multinationality, tax havens, intangible assets, and transfer pricing aggressiveness: An empirical analysis. Journal of International Accounting Research, 14(1), 25-57.

Tiley, J. (2015). Revenue law. Hart Publishing.

Van Aaken, D., Splitter, V., \& Seidl, D. (2013). Why do corporate actors engage in pro-social behaviour? A Bourdieusian perspective on corporate social responsibility. Organization, 20(3), 349-371. 


\section{Ml Macrothink \\ International Journal of Accounting and Financial Reporting ISSN 2162-3082 2018, Vol. 8, No. 4}

Wahab, N. S. A., \& Holland, K. (2012). Tax planning, corporate governance and equity value. The British Accounting Review, 44(2), 111-124.

Walsham, G. (2006). Doing interpretive research. European journal of information systems, 15(3), 320-330.

Wang, X. (2011). Tax avoidance, corporate transparency, and firm value.

\section{Notes}

Note 1. Although not explicitly stated by the cited papers, their approach of fusing known governance mechanisms (structures) to explain tax avoidance (planning) variations suggest structure-actor dualism.

Note 2. Big four" audit firms comprises Deloitte, PwC, Ernst \& Young and KPMG

\section{Copyright Disclaimer}

Copyright for this article is retained by the author(s), with first publication rights granted to the journal.

This is an open-access article distributed under the terms and conditions of the Creative Commons Attribution license (http://creativecommons.org/licenses/by/4.0/) 